\title{
Prisoners' views of CSI's portrayal of forensic identification technologies: a grounded assessment
}

\author{
Helena Machado* \\ Research Centre for the Social Sciences, University of Minho and Centre for Social \\ Studies, University of Coimbra, Portugal
}

\begin{abstract}
Drawing on interviews with prison inmates in Portugal, the aim of this paper is to contribute towards a more practical approach and greater sensitivity to the situatedness of the so-called CSI effect by examining the heterogeneous elements involved in the construction of meanings for forensic science and technology. It discusses the ways in which this particular group's representations of forensic genetics reveal forms of exposure to, but also distancing from, the cultural images circulated by the media. The results indicate that, given that they are in an advantageous position for acquiring knowledge of these issues, this group is relatively skeptical of fictionalized portrayals of DNA technology as infallible and as the most powerful tool that can be used to solve crime. Prison inmates construct a grounded assessment of forensic technologies that derives from the position they occupy in the real world of crime and criminal investigation.
\end{abstract}

Keywords: CSI effect; prisoners; forensic science

\section{Introduction}

Popular and academic discussion of how the media portrays the uses of forensic identification technology in criminal investigation work and the effects this may have on different audiences has been restricted to the role of television and its impact on different actors in the criminal justice system. Most of the debate has unfolded around the so-called CSI effect, a reference to Crime Scene Investigation (CSI), the most popular television crime drama in the world (Brewer and Ley 2009, p. 111). Considerable attention has been directed towards the possible influence of this TV show on jury decision-making in criminal trials. Although there is no consensus on the direction of the expected impacts, it seems to be generally assumed that CSI may influence jurors to place more weight on forensic evidence produced using high-tech tools - in particular, DNA evidence - than on other kinds of evidence (Podlas 2006, Tyler 2006a, Cole and Dioso-Villa 2007, 2009, Robbers 2008).

*Email: hmachado@ics.uminho.pt

ISSN 1463-6778 print/ISSN 1469-9915 online 
High-tech crime dramas circulate cultural images which reflect dominant and taken-for-granted assumptions about crime and criminals (Jewkes 2004), the work of investigators and the authoritative power of forensic identification techniques, in particular the interpretation of DNA fingerprinting as "infallible evidence" (McCartney 2006). This imagery is constructed and perpetuated not only by popular television shows but also by journalists, lawyers and legal scholars (Lynch et al. 2008, p. xi).

Literature on the alleged CSI effect has also discussed the influence of the television series in shaping perceptions of DNA technology, crime scene examination procedures and the identification of offenders on audiences who are removed from the real world of criminal investigation and the work of the law courts. Hence the prevailing focus on the influence of CSI and its clones on juries - ordinary citizens summoned by the courts to assess criminal cases that may be complex and may involve DNA evidence.

The aim of this article is to extend the scope of the debate on the CSI effect through an analysis of 31 qualitative interviews with prison inmates in Portugal. It discusses the ways in which this particular group's representations of forensic genetics reveal forms of exposure to, but also a distancing from, the cultural images circulated by the media which portray DNA evidence as highly reliable and almost infallible. The intention is to contribute towards a more practical approach and greater sensitivity to the situatedness of the CSI effect by emphasizing the fundamental role of the personal experiences of prisoners and the fact that they are in an advantageous position to acquire knowledge of forensic identification technologies, due to their place in the real world of crime and criminal investigation.

An approach is proposed which provides a comprehensive understanding, taking into account the various heterogeneous elements involved in the construction of meanings for forensic science and technology (Mopas 2007). This analysis is empirically supported by the narratives produced by prison inmates in Portugal, paying particular attention to the ways in which this social group's representations of forensic genetics, crime scene work and criminal practices reveal translation processes that combine social actions and material elements (ibid.). These social actions express the social position of the convicted criminals within a network of heterogeneous actors that includes human actors (criminals, the police and law enforcement authorities, and society in general) and non-human actors (technical elements such as DNA profiling and fingerprinting).

\section{The CSI effect: embracing complexity}

The structure and narrative logic of television series such as CSI combine the traditional elements of the genre, such as the melodrama of the police force involved in fighting violent crime, with elements associated with the aura of infallibility surrounding forensic technology and laboratory procedures. The episodes usually begin with the discovery of a crime, followed by the recovery and analysis of 
traces and various interrogations, and culminate in the suspect being confronted with the evidence and their subsequent confession in the face of its apparently implacable certainty. As such, CSI offers a repertoire of wishful-thinking science (Kruse 2010), envisaging a better society in which crime is eradicated with the aid of forensic science.

Various authors argue that this unique combination of melodramatic elements, easily perceived as fiction, and elements derived from technology and DNA evidence associated with the myth of infallibility and the ability to produce the truth (Podlas 2006, Mopas 2007, Lynch et al. 2008), makes it difficult to distinguish between fiction and reality (Cavender and Deutsch 2007, Deutsch and Cavender 2008). CSI therefore appears to produce something hybrid which has also been described as a "blurred line between the hard facts of reality and the soft, quick solutions of entertainment" (Durnal 2010, p. 1).

The idea that CSI incorporates a fusion of fictional elements, destined to entertain audiences, and serious elements - such as the work of the police authorities and forensic scientists engaged in combating violent crime through the use of highly sophisticated technologies - has fueled the debate on the so-called CSI effect.

This discussion has produced three main lines of argument concerning the potential effects created by the exposure of different audiences to the content of television programs such as CSI, which I consider important in embracing the complexity of the cultural meanings constructed by prison inmates when talking about the TV show and which I called the "moral authority effect," the "(credible) distortion of reality effect," and the "educational effect." These three possible effects of viewing CSI will be explained in the next section, and it will later be argued that prisoners' narratives on this television series reveal a combination of all three types of impact.

The moral authority effect corresponds to the idea that CSI reinforces the belief in science as producing certainty and truth, therefore enabling crimes to be solved and the common good to be reinforced (Gever 2005). At the same time, it consolidates the moral authority of the police (Jackson and Bradford 2009) in making use of sophisticated technology during the course of their work (Deutsch and Cavender 2008, Williams and Johnson 2008). The overall impact of this effect is what Cavender and Deutsch describe as a "new forensic realism to fuse the police and science with a convergent moral authority" (2007, p. 68). In concrete terms, the "moral authority effect" of CSI is seen as being able to create more public support for the expansion of DNA databases and more intensive use of forensic technologies to catch criminals (Cutter 2006, Brewer and Ley 2009, Innes and Clarke 2009), while also reinforcing punitive visions and surveillance by highlighting the benefits of using forensic technologies to fight and prevent crime (Duster 2004, Neyroud and Disley 2008, Hindmarsh 2010, Williams 2010).

The "(credible) distortion of reality effect" is produced by the fact that, in CSI, criminal investigation work, invested with the power of science, is presented without any of the ambiguities and uncertainties of the real world, offering certainty 
and condemning the guilty (Cavender and Deutsch 2007, pp. 68-69). Images of forensic science, identification technologies based on DNA profiling and the actual investigators are based on close resemblance to certain techniques used in real life, constructing culturally valid meanings. CSI presents what Deutsch and Cavender (2008) call a creative sense of forensic realism which ignores the contingencies associated with DNA technology in the real world. This aspect of the CSI effect has been cited as leading juries in adversarial justice systems to over-value DNA evidence (Podlas 2006, Tyler 2006a, 2006b, Robbers 2008) and creating unrealistic expectations regarding police investigative work and the effective power of forensic technologies in solving criminal cases (Huey 2010).

Finally, the "educational effect" takes two separate and even contradictory forms, producing a "'hypothesis swapping' in which evidence supporting one supposed effect was used to support claims about the existence of a different effect" (Cole and Dioso-Villa 2009, p. 1346). One aspect of the "educational effect" is related to the argument that viewing CSI is beneficial, since it makes the public better able to interpret and assess scientific evidence if they have to serve on a jury in a criminal trial. A second aspect of the CSI educational effect emphasizes the negative impacts of watching the program, alleging that the series serves to educate criminals or potential criminals, by teaching them and encouraging them to remove clues from crime scenes and making them more sophisticated. This negative educational effect is generally cited by the police, who claim that criminals become cleverer, making the work of the authorities more difficult (Durnal 2010). It is plausible that "professional" criminals, who plan crimes and take the type of technologies used by the police into account, have become, to a certain extent, informal crime scene experts, as suggested by Prainsack and Kitzberger (2009), in the sense that they leave no traces.

\section{Morality, fictionalized realism and educational impacts}

A pioneering work on criminals' views of forensic identification technologies was produced by Prainsack and Kitzberger (2009). Although the authors were more interested in approaching "other ways of understanding DNA in the field of criminal investigation" than discussing the CSI effect among offenders, they came to the conclusion that prison inmates also acquire a knowledge of forensic DNA technologies from the TV series, but combine this knowledge with (criminal) expertise on managing the risks of being caught (Prainsack and Kitzberger 2009, pp. 52-53). Another fundamental contribution to our understanding of criminals' representations of DNA technology can be found in Prainsack's analysis of the differences and similarities in the understanding of, and attitudes towards, forensic DNA technologies demonstrated by law enforcement agencies and prisoners (Prainsack 2010), in which the author shows how those who use forensic DNA technologies reveal a rather nuanced understanding of the probative value of DNA evidence, while prisoners tend to regard DNA profiling as infallible and true (Prainsack 2010, p. 171). 
It is generally accepted that individuals are not passive receptors of the media (Sacco 1995), but when the information in question concerns matters that are further removed from their everyday experience, the reality that is transmitted to the audiences is shaped and contextualized by journalists (McCombs 2004, p. 1). In other words, can it be said that the further removed individuals are from the everyday routines of criminal investigation work, the more vulnerable they are to the CSI effect? If this hypothesis can be accepted in theoretical terms, what does this mean in empirical terms? That individuals who are more distant from the real world of criminal investigation are more ready to believe that science and police work based on advanced forensic technologies are totally efficient and always correctly identify the perpetrators of crimes? If we accept that this hypothesis is sound, how should we consider the kinds of influence to which individuals closely involved in the routine work portrayed in CSI are subjected, namely police investigators, forensic scientists - and, of course, criminals themselves? Is this group - which is very heterogeneous and occupies specific places within the social hierarchy and power relationships - more skeptical of the images projected by CSI of science and technology used in criminal investigations?

Some authors consider that specialists in forensic science and criminal investigation work reveal a more critical attitude towards such fictional portrayals of forensic science than laypersons. As Lynch and co-authors demonstrate, experienced forensic scientists are quick to point out that the reality of forensic science is far less clear and certain than what is portrayed on television (Lynch et al. 2008, p. x). Following a different line of reasoning, Huey (2010) explores how police officers perceive the impact of unrealistic images of police work in television programs on the public's perceptions of their own work and duties, suggesting that the police also tend to think that the high-tech science portrayed by the media is far removed from reality. Prainsack argues that while convicted criminals tend to regard forensic DNA profiling as infallible and true, law enforcers had a rather nuanced understanding of the probative vale of DNA evidence, emphasizing that the meaningfulness of DNA technologies lies in the social and professional contexts of their use (Prainsack 2010, p. 171).

This article argues that it is necessary to develop an analysis of the CSI effect that is able to capture the complexity and heterogeneity of its various impacts in local, socially and culturally determined contexts. It is necessary to consolidate the tools that capture the hybrid and diverse nature of the impacts that may be produced in different audiences, both law-abiding citizens and potential or convicted criminals, whether they are familiar with crime scene examination procedures in criminal investigation work and the weight given to forensic evidence in court, or not.

My focus is similar to the approach proposed by Duster (2006) when explaining the differential trust of DNA forensic technology: the author argues that while some people see DNA evidence as definitive, others (like Africans and Latinos living in major cities in the USA) remain highly skeptical because they consider that DNA technology may not be used fairly in a criminal justice system that is tainted and 
corrupted (Duster 2006, p. 294). Duster proposes the concept of "grounded assessment" as an approach to views on DNA technology to explain why there are sharp differences in perceptions of developments in DNA technology and forensics, by which underprivileged ethnic minorities are more inclined to express distrust and suspicion grounded on their previous negative experiences with the criminal justice system. This concept is borrowed here in order to explore how Portuguese prison inmates view DNA technologies by making sense of what they see on television by merging certain elements of the fictional representations of high-tech crime scene work with their own experiences of dealing with the criminal justice system, as well as their particular perceptions of criminal activities and the work of the crime investigation authorities.

\section{A grounded assessment of CSI portraits of forensic science}

After obtaining authorization from the Portuguese General Board of Prison Services, 31 semi-structured interviews were conducted with inmates in three prisons for adult males in the north of Portugal between May and September 2009. The aim was to analyze the prisoners' social representations of the potential of the national forensic DNA database, established in Portugal by Law 5/2008 of 12 February, for preventing and deterring crime. The selection of interviewees was devised as a theoretical sample, based on representativeness by diversity and exemplariness (Hamel et al. 1993), and conjugated with a convenience sampling by considering the individuals that would be more predisposed to participate in this study, according to the information gathered by the administration in each prison.

The prisoners interviewed were mostly primary offenders $(n=24)$ and the crimes which led to their incarceration were: homicide $(\mathrm{n}=11)$; rape and/or sexual abuse of minors $(n=8)$; theft $(n=8)$; drug trafficking $(n=4)$; driving without a license $(n=2)$; and qualified fraud $(n=1)$. The length of the sentences varied between under three years to 25 years. We must emphasize that 20 of the 31 interviewed inmates were given a sentence which was more than five years and less than 20 years in prison (for more methodological details, see Machado et al. 2011). One of the topics in the interview script was related to the prisoners' main sources of information on DNA and on the uses of forensic genetics in criminal investigation. Using the responses to this topic, it was possible to capture many narratives spontaneously produced by prisoners concerning the CSI television series.

The prison inmates revealed a rather complex range of sources of knowledge of criminal investigation and forensic technologies that could not be explained simply by reference to watching television crime drama (Prainsack and Kitzberger 2009). Although a large majority of respondents mentioned television as the main source of their knowledge of crime scene traces, with specific references to CSI - in the case of 19 out of 31 individuals - crime drama was not the only media genre they cited as providing information on criminal investigation and forensic identification techniques. Some individuals referred to several other TV genres, such as news 
broadcasts and documentaries that describe the use of forensic genetics in criminal investigation work, which indicates the importance of considering how multiple forms of media use relate to the general public's perceptions of DNA evidence (Brewer and Ley 2009, p. 99). Other sources were also cited by the prison inmates: the press, conversations with other prisoners, the internet, radio, school and personal experience of dealing with the criminal justice system. For the purposes of this article I will focus only on the prison inmates' narratives associated with the CSI TV show.

While literature on the subject suggests that it might be difficult for the ordinary viewer to distinguish between reality and fiction when confronted with CSI's forensic realism, these prison informants were able to establish a dividing line between fiction and reality. Although representations of crime scene work in the popular media allegedly lack the uncertainties and ambiguities of crime scene work in "the real world," some prison inmates may have experienced the reality - how crime scenes are really managed - or may have had conversations with other inmates about this. Prisoners (as well as the authorities and forensic science experts) are in an advantageous position to acquire knowledge which provides the skills to enable them to distinguish between the reality and fiction of the CSI cultural images. The narratives of the prisoners revealed, to a certain degree, how spending time in prison was important to gain skills on how to distinguish what is real and fiction in crime TV series: to talk with other prison inmates was a valuable knowledge source about how to commit a crime or how to decrease the risk of detection and conviction (Beauregard and Bouchard 2010, see also Foucault 1975).

The "(credible) distortion of reality effect" or, in other words, the belief that CSI represents a fictional image of the reality of criminal investigation work but also contains a degree of truth, was described by Valter, a 25-year-old prisoner, sentenced to 18 years for kidnapping, rape and aggravated burglary, when he stated that before he went into prison he thought that "it was all fiction" but after hearing stories from other prisoners began to believe that the television series contained some truth:

Before coming here we had the idea that "Hey, that's television, it's all rubbish. [The criminal investigator] will never know that he is guilty just from a single hair." But then I came to prison and started hearing things like "this was because of a drop of blood he left on a window, and that was because of a speck of blood on his trousers." A guy starts to become more up-to-date, right? By listening to more information on the subject.

Other prisoners explained the fusion between reality and fiction in CSI by stating that CSI illustrates the reality of crime scene investigations in more advanced countries such as the USA and the UK. However, they felt that Portugal's actual resources and methods of carrying out criminal investigation work were far removed from the high science portrayed in CSI because of the lack of equipment to do crime scene work and insufficient training of criminal investigation police. 
Feliciano, aged 32, and serving a 12-year sentence for murder, summarized the attempts by the Portuguese police to become more technologically advanced and the difficulties that arise in those attempts:

The necessary conditions and infrastructures [in order to improve criminal investigation] have to be created [in Portugal]. And I don't like to talk about this, because it seems we are placing Portugal behind countries more ... no, not backwards, but less developed. I believe that it is happening in other countries, if I'm not mistaken, like the United States [of America] and the United Kingdom ... A few months ago they were saying on television that the Portuguese forensic police [sic] received a ... vehicle equipped with everything, like CSI Miami [laughs]. This means that the Portuguese justice is also trying to keep up with its counterparts regarded as more developed. Of course, we don't have many [vehicles equipped with crime scene investigation kits], we have a few, while other countries have plenty, [Portugal] has got just a few. But it will take the necessary qualification, training and maintenance so that the Portuguese agents - mainly the police - have the necessary conditions ... like the great powerful countries have ...

The inmates displayed skepticism or a general mistrust of DNA evidence, since in their own personal experiences with the authorities - when they had been accused of committing a particular crime - or in the reports they had heard from other offenders, DNA had not been used. They considered that the kind of criminal investigation work carried out in Portugal was based much more on fingerprints in the police databases and analysis of the modus operandi of criminals rather than on the use of DNA profiling - which is actually true for forensic crime scene investigations all over the world (Schroeder and White 2009).

The Madeleine McCann case, a high-profile criminal case which unfolded in Portugal in 2007 and received a great deal of media attention worldwide (Machado and Santos 2009), provided a concrete reference point for the perceptions of some prisoners that there are limitations to forensic science and proving, in the opinion of some, that there is a great deal of fiction in the idea conveyed by CSI that DNA is a rapid and infallible means of solving criminal cases almost instantaneously. Artur, 38 years old, sentenced to 12 years for aggravated burglary and theft, mentioned that fingerprints were probably more effective than DNA in identifying criminals, justifying his opinion on the basis of personal experience and also with reference to the disappearance of Madeleine McCann: ${ }^{1}$

They say that DNA is also efficient. I don't know because I've never been in any of those situations ... Fingerprints, yes, I've had experience of that, right? But I don't know about DNA. [If you look at the Madeleine McCann case] I think that if [DNA] was efficient they would have been able to say whose blood it really was.

The prison inmates were relatively skeptical of the image of forensic science portrayed in CSI: they believed in the potential of DNA to incriminate (or prove innocence) - but did not believe in its efficacy in the real world of criminal investigation work in Portugal. This position on the uses of high-science 
technology - in particular DNA technology - is an example of "grounded assessment," as described by Duster (2006) in a USA context and leads to the debate whether DNA profiling can be viewed by marginalized populations as better or worse for them than traditional policing technologies. As discussed above, the Portuguese inmates seem to prefer a technology that is very intrusive but is perceived as fair and egalitarian. A considerable number of inmates claimed that additional intensive and extensive uses of forensic DNA databases were desirable because more "scientific tools" might be more protective of their own individual rights, possibly increasing potential for exoneration or at least protecting them from illegal and incriminatory police actions such as planting biological evidence in crime scenes, forcing confessions or using snitches (Machado et al. 2011, Machado and Prainsack 2012). In the words of Tomás, 28 years old, convicted of rape and murder, there were ethical questions raised by the creation of a forensic DNA database that covered the entire population, but concluded that the benefits outweighed the risks of repression and the threat to individual rights:

I know that a universal database would create a big ethical problem in terms of violating freedoms ... but really I think it should be extended - I'm being a bit radical here - to all individuals. It should cover the whole [Portuguese] population.

The fact that DNA technology is perceived as something distant from the reality of criminal investigation work in Portugal served as the grounds for prisoners to reveal, through their narratives, a combination of the "(credible) distortion of reality effect" and the "moral authority effect": the overwhelming majority of interviewees conveyed the notion that ideally criminal investigation should function as it does in the television series, that is, by resorting to advanced and totally efficient technology to identify the perpetrators of crimes. They therefore projected a wishful-thinking moral authority, arguing that in an ideal world forensic technologies should be used to solve crimes and thus contribute to the common good. In this ideal world in which criminal investigation is principally based only on high-science technology - as is the case with CSI - a state of automation can be reached in which the truth is determined by technology. This belief that technology may, in the future, solve various problems faced by prisoners - incriminatory police practices and the subjective nature of court rulings - perhaps explains why 12 out of 31 prisoners supported the creation of a universal DNA profile database (i.e. one which covers the entire population). As Feliciano, whom we encountered before in this paper, mentioned:

You just need to input the data, right? And, automatically, the [DNA] database carries out an instant search - I think - and a few minutes later, or less, it will confirm whether [the profile] really matches the individual or not ... it will speed up investigations and save time $[\ldots]$ the faster justice works, the faster things can improve.

DNA technology was perceived as something that could potentially eliminate the contingencies and discrimination generated by the human actors in the criminal 
justice system and therefore strengthen the moral authority of police work through the use of science, which they saw as neutral and capable of reaching the truth. Television culture fosters expectations concerning the absolute certainty of traces or DNA evidence and the "easy" and rapid way in which the police can solve complex criminal cases (Hughes and Magers 2007, p. 261). This creation of unrealistic expectations appears to increase negative assessments of the work of the Portuguese police. In fact, the existence of real-life criminal cases, widely publicized in the media, in which DNA did not reveal the solution to the crime may reinforce images of the inefficiency of the Portuguese police (Machado and Santos 2009, 2011), which also coincide with negative representations and feelings of alienation with regard to the justice system in Portugal, which is seen as slow, inefficient and discriminatory (Machado and Silva 2010).

Finally, many inmates said that, through news broadcasts and crime dramas such as CSI, television could act as a source of knowledge and learning for criminals, by teaching them and encouraging them to eliminate traces from crime scenes and making them more sophisticated - something which has been reported in literature on the subject, such as the "CSI effect - police chiefs' version" (Cole and DiosoVilla 2007, p. 452). These opinions were framed by a law-abiding stance in which the educational effect acquired meaning for individuals from a moral perspective. Being knowledgeable about how to avoid leaving traces at crime scenes, showing an interest in TV crime dramas, or even talking about TV crime series, seemed to be viewed by some interviewees with suspicion as a sign of being a "real" criminal or of having criminal intentions, i.e., something which they wanted to distance themselves from. Other inmates emphasized the negative effect of criminals watching TV series such as CSI and expressed concerns about the potential harmful effects. Joel, 22 years old, serving a sentence of five years and six months for aggravated rape, expressed his concern regarding the instrumental value of the knowledge obtained by watching CSI:

CSI is fiction, but it teaches you how to commit a crime ... [One day] we were watching CSI and my mate even said "look, they're teaching us how we should kill a person." We laughed and joked about it, but it's actually true ... CSI teaches you a lot ... how a person can be protected from incriminating evidence ... That is what I don't agree with.

In stating that TV series can teach criminals how to avoid leaving DNA traces at crime scenes but adding that they "aren't interested in that," the interviewees seem to have reconstructed their identities in a prison context by exteriorizing what they believe to be a socially acceptable identity (Goffman 1959, 1963). Prisoners appeared to talk about criminals with a sense of "otherness," adopting the stance of the righteous citizen. This position expresses an attempt to align themselves with the moral authority of science - perceived as the language of truth. The narratives constructed around television series and views of forensic science associated with media discourses carry with them images of good and evil and 
reflect the co-production of knowledge and social order (Jasanoff 2004) through which prison inmates relate to institutions of power.

\section{Conclusion}

The results indicate the existence of a critical and reflexive stance adopted by the prison inmates in relation to the super-science imagery portrayed in TV crime dramas such as CSI, namely when interviewees stressed the discrepancies between TV fiction and reality and pointed out the weaknesses of DNA technologies due to possible human error or abusive uses by authorities.

DNA technology emerges as an important non-human actor which is involved in the construction of the meanings prisoners attribute to the role of DNA evidence within the justice system. As a result of their negative experiences of the criminal justice system, the majority of prisoners saw the use of DNA in criminal investigation work and the use of DNA forensic databases as a shield that will protect them from the aprioristic and systematic suspicion which they felt the authorities subject those with a criminal past.

Although the majority of the prison informants reproduced the association between DNA and high science, some individuals demonstrated a certain skepticism towards DNA evidence, emphasizing the idea that the probative value of DNA profiling lies in the social contexts of its use. In other words, some prisoners believed that CSI portrays the reality of the more advanced countries, while expressing skepticism regarding the feasibility of the CSI image in Portugal, which they still consider a backward country in terms of the latest technological criminal investigation methods. While some prisoners asserted that the criminal investigation work supported by forensic genetics in this TV series was totally fictional, other individuals thought that it might correspond to some extent with a reality that could emerge in an ideal world or probably in the future. There was also the question of physical and cultural "proximity" (Jewkes 2004, pp. 51-53). The prisoners seemed to be more aware of cases that had occurred close to them and they could gather more information on the actual capabilities of the local police from these sources, i.e., on the basis of real-life cases heavily publicized in the media, from the testimonies of fellow prisoners who had been sentenced on the basis of scientific evidence, or from their own experiences. The arrest and sentencing of criminals may also constitute an important - if not the most important - lesson in forensic science and how to avoid detection in any future crimes. In addition to the experience of arrest and trial, it is highly likely that the level of forensic knowledge increases exponentially during time spent in prison, to the extent that prisons are places that encourage the sharing of experiences and knowledge of the world of crime.

This article also intends to contribute to an understanding of the so-called "police chief's effect" which entails the assumption that CSI educates criminals on how to avoid detection, a topic that still remains underexplored in the literature (for 
exceptions see Prainsack and Kitzberger 2009, Durnal 2010). The views of the Portuguese prison inmates about DNA technology and its uses in criminal investigation cannot simply be explained by the CSI effect. Rather, the prisoners made sense of what they saw on television by merging certain elements of representations of high-tech crime scene work with their own experiences. As well as obtaining knowledge of forensic science and criminal methods, it should be borne in mind that prisoners also construct representations and perceptions of the police force itself, its methods, capabilities and equipment - what I have called a grounded assessment of CSI portrayals of forensic science. These representations are based on the idea of the moral authority of science (Jasanoff 2006) in which the potential educational effect of CSI on criminals acquires the status of legitimate knowledge and proximity to the law-abiding prism.

An analysis of the narratives of prisoners enables the CSI effect to be discussed within a cultural and social context that is separate from the criminal justice system and investigative police work in the USA, the country which produces the television series and on which the debate on the influence of high-tech crime dramas on various audiences has been focused. This article may therefore contribute to an understanding of the potential effects of CSI in social contexts marked by the use of DNA technology to identify criminals that has still not been fully developed, and by the inquisitorial nature of the justice system and police work. These differences in the cultural and judicial context appear to create additional tensions between the fictional images of criminal investigation transmitted by CSI and interpretations of the concrete reality of criminal investigation.

\section{Acknowledgements}

I am extremely grateful to Diana Miranda and Filipe Santos for their involvement in the fieldwork for this study and to Manuela Ivone Cunha for her collaboration in producing the report of this study for the General Board of Prison Services (Portugal). I also would like to express my gratitude for the illuminating comments made by Susana Silva on early drafts of this article and to Barbara Prainsack who provided invaluable guidance throughout the research process and shared personal insights from her own studies on prison inmates' perceptions of DNA technology. The research for this article was supported by the Foundation for Science and Technology (Portuguese Ministry of Education and Science) through a post-doctoral fellowship (SFRH/BPD/34143/2006), the project "Forensic DNA databasing in Portugal: contemporary issues in ethics, practices and policy" (FCOMP-01-0124-FEDER009231) and the project "Justice, media and citizenship" (FCOMP-01-0124-FEDER-007554).

\section{Note}

1. The Madeleine McCann case is the unsolved case of the disappearance of a three-year-old English girl, during a family holiday in a beach resort in Portugal in May 2007. It was one of the most high-profile cases (in terms of media coverage and public attention worldwide) of the decade and was covered by the British and the Portuguese tabloid press in such a dramatic way that could well have been mistaken for a CSI plot (Machado and Santos 2009). The police discovered blood and other biological traces in the McCann's holiday apartment, as well as in their rented car. But while science was portrayed by the tabloid press as the (only) solution for the crime the absence of a scientific explanation for the known facts placed the 
capabilities and limitations of real science against fictionalized representations of forensic science (Machado and Santos 2009).

\section{References}

Beauregard, E. and Bouchard, M., 2010. Cleaning up your act: forensic awareness as a detection avoidance strategy. Journal of Criminal Justice, 38 (6), 1160-1166.

Brewer, P.R. and Ley, B.L., 2009. Media use and public perceptions of DNA evidence. Science Communication, 32 (1), 93-117.

Cavender, G. and Deutsch, S.K., 2007. CSI and moral authority: the police and science. Crime, Media, Culture, 3 (1), 67-81.

Cole, S. and Dioso-Villa, R., 2007. CSI and its effects: media, juries, and the burden of proof. New England Law Review, 41 (3), 435-470.

Cole, S. and Dioso-Villa, R., 2009. Investigating the "CSI effect" effect: media and litigation crisis in criminal law. Stanford Law Review, 61 (6), 1335-1374.

Cutter, A.M., 2006. To clear or to convict? The role of genomics in criminal justice. Genomics, Society and Policy, 2 (1), 1-15.

Deutsch, S.K. and Cavender, G., 2008. CSI and forensic realism. Journal of Criminal Justice and Popular Culture, 15 (1), 34-53.

Durnal, E., 2010. Crime scene investigation (as seen on TV). Forensic Science International, 199 $(1-3), 1-5$.

Duster, T., 2004. Selective arrests, an ever-expanding DNA forensic database, and the specter of an early-twenty-first-century equivalent of phrenology. In: D. Lazer, ed. DNA and the criminal justice system: the technology of justice. Cambridge, MA: MIT Press, 315-334.

Duster, T., 2006. Explaining differential trust of DNA forensic technology: grounded assessment or inexplicable paranoia? Journal of Law, Medicine \& Ethics, 34 (2), 293-300.

Foucault, M., 1975. Discipline and punish: the birth of the prison. New York: Random House.

Gever, M., 2005. The spectacle of crime, digitized. CSI: crime scene investigation and social anatomy. European Journal of Cultural Studies, 8 (4), 445-463.

Goffman, E., 1959. The presentation of self in everyday life. London: Penguin.

Goffman, E., 1963. Stigma: notes on the management of spoiled identity. New York: Simon \& Schuster.

Hamel, J., Dufour, S., and Fortin, D., 1993. Case study methods. London: Sage.

Hindmarsh, R., 2010. Biosurveillance and biocivic concerns, from "truth" to "trust": the Australian forensic DNA terrain. In: R. Hindmarsh and B. Prainsack, eds. Genetic suspects: global governance of forensic DNA profiling and databasing. Cambridge: Cambridge University Press, 262-287.

Huey, L., 2010. "I've seen this on CSI": criminal investigators' perceptions about the management of public expectations in the field. Crime, Media, Culture, 6 (1), 49-68.

Hughes, T. and Magers, M., 2007. The perceived impact of crime scene investigation shows on the administration of justice. Journal of Criminal Justice and Popular Culture, 14 (3), 259-276.

Innes, M. and Clarke, A., 2009. Policing the past: cold case studies, forensic evidence and retroactive social control. British Journal of Sociology, 60 (3), 543-563.

Jackson, J. and Bradford, B., 2009. Crime, policing and social order: on the expressive nature of public confidence in policing. British Journal of Sociology, 60 (3), 493-521.

Jasanoff, S., ed., 2004. States of knowledge: the co-production of science and social order. London: Routledge.

Jasanoff, S., 2006. Just evidence: the limits of science in the legal process. Journal of Law, Medicine \& Ethics, 34 (2), 328-341.

Jewkes, Y., 2004. Media and crime. London: Sage. 
Kruse, C., 2010. Producing absolute truth: CSI science as wishful thinking. American Anthropologist, 112 (1), 79-91.

Law $5 /, 2008$. Approves the creation of a DNA profiles database for civil and criminal identification purposes. Diário da República, series 1, 30 (2008), 962-968.

Lynch, M., et al., 2008. Truth machine: the contentious history of DNA fingerprinting. Chicago: University of Chicago Press.

Machado, H. and Prainsack, B., 2012. Tracing technologies: prisoners' views in the era of CSI. Farnham: Ashgate.

Machado, H. and Santos, F., 2009. The disappearance of Madeleine McCann: public drama and trial by media in the Portuguese press. Crime, Media, Culture, 5 (2), 146-167.

Machado, H. and Santos, F., 2011. Popular press and forensic genetics in Portugal: expectations and disappointments regarding two cases of missing children. Public Understanding of Science, 20 (3), 303-318.

Machado, H. and Silva, S., 2010. Portuguese forensic DNA database: political enthusiasm, public trust and probable issues in future practice. In: R. Hindmarsh and B. Prainsack, eds. Genetic suspects: global governance of forensic DNA profiling and databasing. Cambridge: Cambridge University Press, 218-239.

Machado, H., et al., 2011. Stained bodies: prisoners' perceptions of the DNA database for criminal investigation purposes and their perspectives of social reintegration [online]. Coimbra: Centro de Estudos Sociais. Available from: http://dnadatabase.ces.uc.pt [Accessed 21 May 2012].

McCartney, C., 2006. The DNA expansion programme and criminal investigation. British Journal of Criminology, 46 (2), 175-192.

McCombs, M., 2004. Setting the agenda: the mass media and public opinion. Cambridge: Polity Press.

Mopas, M., 2007. Examining the "CSI effect" through an ANT lens. Crime, Media, Culture, 3 (1), $110-117$.

Neyroud, P. and Disley, E., 2008. Technology and policing: implications for fairness and legitimacy. Policing, 2 (2), 226-232.

Podlas, K., 2006. The "CSI effect": exposing the media myth. Fordham Intellectual Property, Media and Entertainment Law Journal, 16, 429-465.

Prainsack, B., 2010. Partners in crime: the use of forensic DNA technologies in Austria. In: Genetic suspects: global governance of forensic DNA profiling and databasing. Cambridge: Cambridge University Press, 153-174.

Prainsack, B. and Kitzberger, M., 2009. DNA behind bars: other ways of knowing forensic DNA technologies. Social Studies of Science, 39 (1), 51-79.

Robbers, M., 2008. Blinded by science: the social construction of reality in forensic television shows and its effect on criminal jury trials. Criminal Justice Policy Review, 19 (1), 84-102.

Sacco, V.F., 1995. Media constructions of crime. The ANNALS of the American Academy of Political and Social Science, 539 (1), 141-154.

Schroeder, D.A. and White, M.D., 2009. Exploring the use of DNA evidence in homicide investigations: implications for detective work and case clearance. Police Quarterly, 12 (3), 319-342.

Tyler, T.R., 2006a. Viewing CSI and the threshold of guilt: managing truth and justice in reality and fiction. Yale Law Journal, 115 (5), 1050-1085.

Tyler, T.R., 2006b. Is the CSI effect good science? The Yale Law Journal Pocket Part, 115, 73-75.

Williams, R., 2010. DNA databases and the forensic imaginary. In: R. Hindmarsh and B. Prainsack, eds. Genetic suspects: global governance of forensic DNA profiling and databasing. Cambridge: Cambridge University Press, 131-152.

Williams, R. and Johnson, P., 2008. Genetic policing: the use of DNA in criminal investigations. Cullompton: Willan. 